\title{
Article \\ QuEChERS LC-MS/MS Screening Method for Mycotoxin Detection in Cereal Products and Spices
}

\author{
Licia Pantano ${ }^{1}{ }^{\mathbb{D}}$, Ladislao La Scala ${ }^{1}$, Francesco Olibrio ${ }^{1}$, Francesco Giuseppe Galluzzo ${ }^{1,2, * \mathbb{D}}$, \\ Carmelo Bongiorno ${ }^{1}$, Maria Drussilla Buscemi ${ }^{1}{ }^{\mathbb{D}}$, Andrea Macaluso ${ }^{1}$ and Antonio Vella ${ }^{1}$ \\ 1 Istituto Zooprofilattico Sperimentale della Sicilia, Via Gino Marinuzzi 3, 90129 Palermo, Italy; \\ licia.pantano@izssicilia.it (L.P.); ladislao.lascala@gmail.com (L.L.S.); francesco.olibrio@gmail.com (F.O.); \\ bongiornocarmelo81@gmail.com (C.B.); drussilla.buscemi@izssicilia.it (M.D.B.); amaca258@gmail.com (A.M.); \\ laboratorio.residui@gmail.com (A.V.) \\ 2 Dipartimento di Scienze della Vita, Università degli studi di Modena e Reggio Emilia, Via Università 4, \\ 41121 Modena, Italy \\ * Correspondence: francescogiuseppe92@gmail.com; Tel.: +39-0916565258
}

\section{check for}

updates

Citation: Pantano, L.; La Scala, L.; Olibrio, F.; Galluzzo, F.G.; Bongiorno, C.; Buscemi, M.D.; Macaluso, A.; Vella, A. QuEChERS LC-MS/MS Screening Method for Mycotoxin Detection in Cereal Products and Spices. Int. J. Environ. Res. Public Health 2021, 18, 3774. https:// doi.org/10.3390/ijerph18073774

Academic Editors: Martin David Rose and Paul B. Tchounwou

Received: 20 January 2021

Accepted: 2 April 2021

Published: 4 April 2021

Publisher's Note: MDPI stays neutral with regard to jurisdictional claims in published maps and institutional affiliations.

Copyright: (c) 2021 by the authors. Licensee MDPI, Basel, Switzerland. This article is an open access article distributed under the terms and conditions of the Creative Commons Attribution (CC BY) license (https:// creativecommons.org/licenses/by/ $4.0 /)$
Abstract: We developed and validated a screening method for mycotoxin analysis in cereal products and spices. Ultra-high-performance liquid chromatography coupled with tandem mass spectrometry (UHPLC-MS/MS) was used for the analysis. Dispersive solid-phase extractions (d-SPEs) were used for the extraction of samples. Ochratoxin A (OTA), zearalenone (ZEA), aflatoxins (AFLA; $\mathrm{AFB}_{1}, \mathrm{AFB}_{2}$, $\mathrm{AFG}_{1}, \mathrm{AFG}_{2}$ ), deoxynivalenol (DON), fumonisin (FUMO; $\mathrm{FB}_{1}, \mathrm{FB}_{2}, \mathrm{FB}_{3}$ ), $\mathrm{T} 2$, and $\mathrm{HT} 2$ were validated in maize. AFLA and DON were validated in black pepper. The method satisfies the requirements of Commission Regulation (EC) no. 401/2006 and (EC) no. 1881/2006. The screening target concentration (STC) was under maximum permitted levels (MLs) for all mycotoxins validated. The method's performance was assessed by two different proficiencies and tested with 100 real samples.

Keywords: mycotoxin; QuEChERS; LC-MS/MS; spices; cereals

\section{Introduction}

Mycotoxins represent a group of secondary metabolites with different pharmacological and toxicological aspects [1]. Alkaloids of Claviceps purpurea such as ergotamine, ergometrine, and semi-synthesis derivate have been used in the therapy of Parkinson's disease, post-partum hemorrhage, and hemicrania [2]. The toxicological effects of other mycotoxins, such as aflatoxins ( $\mathrm{AFLA} ; \mathrm{AFB}_{1}, \mathrm{AFB}_{2}, \mathrm{AFG}_{1}, \mathrm{AFG}_{2}$ ), fumonisin (FUMO; $\mathrm{FB}_{1}$, $\mathrm{FB}_{2}, \mathrm{FB}_{3}$ ), deoxynivalenol (DON), T-2, and HT-2, have been well documented and studied in the literature [3-6].

Mycotoxicosis is a human and animal disease caused by ingestion, inhalation, or skin contact of mycotoxins [7]. The symptoms, target organ of systemic toxicity, and clinical outcome depend on several parameters such as type of mycotoxins, intake levels, time, and route of exposures [8]. Mycotoxicosis can be acute or chronic, and different symptoms characterize these two forms.

$\mathrm{AFB}_{1}, \mathrm{AFB}_{2}, \mathrm{AFG}_{1}$, and $\mathrm{AFG}_{2}$ are produced by fungi of the genus Aspergillus. The most representatives fungi that produce AFLA are Aspergillus flavus and Aspergillus parasiticus $[9,10]$. AFLA are characterized by a lipophilic structure (Figure 1) derived from the same precursor, versiconal hemiacetal acetate [11].

The acute ingestion of AFLA (aflatoxicosis) can lead to several symptoms that include gastrointestinal problems (diarrhea, abdominal pain), nervous system dysfunctions (epilepsy, coma), liver damage (jaundice, hepatitis), and even death [12,13]. Chronic exposure to AFLA is associated with multiple-organ cancer, immunosuppression, and other diseases [14]. $\mathrm{AFB}_{1}, \mathrm{AFB}_{2}, \mathrm{AFG}_{1}$, and $\mathrm{AFG}_{2}$ are classified as group 1 (carcinogenic to humans) by the Agency of Research on Cancer (IARC) and have mutagenic and teratogenic effects in humans [15]. Once ingested, AFLA are converted by cytochrome P450 
into high reactive epoxides that can create adducts with nucleobases [16]. Hepatocellular carcinoma (HCC) is strictly correlated with dietary exposure to $\mathrm{AFB}_{1}$ and adducts excreted in urine $[17,18]$.<smiles>COc1cc2c(c3oc(=O)c4c(c13)CCC4=O)[C@H]1C=CO[C@@H]1O2</smiles>

(a)

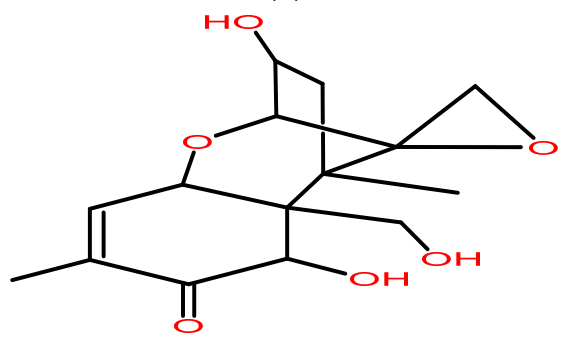

(c)

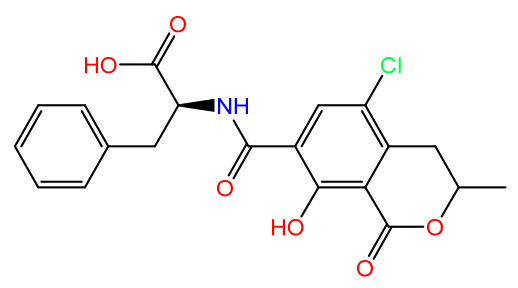

(e)

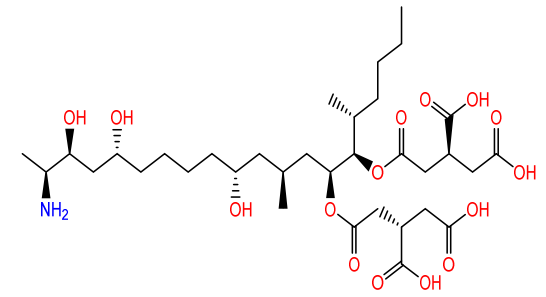

(b)<smiles>N[C@@H](Cc1cc(I)c(Oc2ccc(O)cc2)c(I)c1)C(=O)O</smiles>

(d)<smiles>CO[C@H](C)CCCC(=O)CCC/C=C/c1cc(O)cc(O)c1C(=O)O</smiles>

(f)

Figure 1. Molecular structure of some mycotoxins: (a) $\mathrm{AFB}_{1}$; (b) $\mathrm{FB}_{1}$; (c) deoxynivalenol (DON); (d) T2; (e) ochratoxin A (OTA); (f) zearalenone (ZEA).

FUMO $\left(\mathrm{FB}_{1}, \mathrm{FB}_{2}, \mathrm{FB}_{3}\right)$ are produced by fungi of the genus Fusarium [19]. $\mathrm{FB}_{1}$ contamination is common in cereals, and it is the most toxic FUMO [20]. Acute ingestion of FUMO can cause gastrointestinal problems, and they are considered possibly carcinogenic to humans (group 2B) by IARC $[15,21]$. FUMO can interfere with folic acid metabolism (teratogenic effects), cause inhibition of sphingolipid biosynthesis, and have carcinogenic effects $[11,21]$. They are polar compounds and are not soluble in non-polar solvents (Figure 1) [21]. Chronic exposure to $\mathrm{AFB}_{1}$ and $\mathrm{FUMO}$ can lead to liver cancer (sum of carcinogenic effect) [22].

Fusarium species also produce DON, which is one of the most common mycotoxins in cereals [23]. It is considered not classifiable as to carcinogenicity to humans (group 3) [15]. The acute toxicity is mainly gastrointestinal, with nausea, diarrhea, and abdominal pain [24] DON is also called vomitoxin since it can induce emesis [25]. It can also cause dysfunctions of the immune, neuroendocrine, and cardiovascular systems [26]. DON is a polar molecule that can resist at high temperatures, and it is soluble in polar organic solvents $[27,28]$. It is classified as non-macrocyclic trichothecenes [29].

Non-macrocyclic trichothecenes also include T2 and HT2 (C-4 deacetylated form of T2, Figure 1) produced from Fusarium species [30]. The name derived from trichothecin, the first non-macrocyclic trichothecene isolated in 1948 from Trichothecium roesum [11]. T2 is the most toxic among all trichothecene [31]. T2 and HT2 have been reported frequently in cereal-based products [32,33]. Acute toxicity symptoms are similar to DON [34]. T2 can inhibit DNA, RNA, and protein synthesis [35]; can induce apoptosis; and has immunotoxic effects [32]. T2 and HT2 can resist temperature, and they are deactivated by low or high $\mathrm{pH}$ [35]. 
Ochratoxin A (OTA) is the most important and toxic mycotoxin among ochratoxins [36]. It is an isocumaric derivate with a $\beta$-phenylalanine (Figure 1) [11]. Aspergillus and Penicillium species can produce OTA; Aspergillus ochraceus and Penicillium verrucosum are the most common [37]. It is located in group 2B in the IARC classification [15]. Its toxicological activity can affect neuronal, renal, and immune systems [36]. OTA has a high affinity for serum albumin and, therefore, it is characterized by a high plasma half-life [38]. It has been found in several foods such as milk, coffee, wine, and vegetables [38]. It also has been reported in baby food [39]. OTA is soluble in polar organic solvents [40].

Zearalenone (ZEA) is a resorcylic acid lactone (Figure 1) produced by the Fusarium genus species [8]. It is classified as group 3 by IARC [15]. It is associated with endocrine alteration with clinical manifestations of hyperestrogenism [41]. Swine are the most sensitive species to the toxic effects of ZEA; clinical signs of acute mycotoxicosis are swelling of the vulva, prolonged estrus, pseudopregnancy, and infertility [37]. ZEA can be found in crops, wheat, maize, and snacks [42].

Mycotoxins in food are unavoidable contaminants [13]. High temperatures and bad storage conditions can increase mycotoxin contamination in food [43-46]. They can resist standard cooking methods [47-49], leading to serious health concerns [33].

In developing countries, there have been relatively recent episodes of mycotoxicosis. One-hundred and twenty-five people died in Kenya (Africa) in 2004 [50], and there were 100 victims in 1974 in India [51]. There were alimentary toxic aleukia (ATA) cases in the USSR in the 1950s associated with consuming trichothecenes in wheat [37].

Cereals such as maize, oat, and wheat are considered the most susceptible to mycotoxin contamination [52-59]. It was proven that 25\% of cereals consumed in the world in 1988 were contaminated by mycotoxins [60]. Products derived from cereals such as pasta, bread, and snacks can contain cereal-derived mycotoxins [61,62].

One of the biggest problems related to the cereal contaminations of mycotoxin is the carry-over effect. Mycotoxins consumed in feeding stuff are absorbed and metabolized by animals and can be found in meat, eggs, and milk [63].

Different cereal-based products for human consumptions are mixed with black pepper for flavoring purposes or preservatives, leading to possible increases in mycotoxin contents [60]. Spices are usually dried on the ground in the open air in poor hygienic conditions that promote the growth of molds and production of mycotoxins $[64,65]$. The Rapid Alert System for Food and Feed (RASFF) reported that the third most common matrices with AFLA in Europe are herbs and spices [66].

The Commission Regulation (EC) no. 401/2006 established MLs of mycotoxins for different food and feed [67]. AFLA $\left(\mathrm{AFB}_{1}\right.$, the sum of $\left.\mathrm{AFB}_{1}+\mathrm{AFB}_{2}+\mathrm{AFG}_{1}+\mathrm{AFG}_{2}, \mathrm{AFM}_{1}\right)$, OTA, patulin, DON, ZEA, FUMO $\left(\mathrm{FB}_{1}+\mathrm{FB}_{2}\right)$, T-2 and HT-2, citrinin, ergot sclerotia, and ergot alkaloids were regulated in Europe. The regulation does not consider the assessment of exposure to the sum of mycotoxins [33] with potentially higher exposure. Furthermore, the presence of masked mycotoxins can lead to an underestimation of their concentration in a sample [68].

There are several analytical techniques to analyze mycotoxin in different matrices [69-73]. HPLC methods associated with fluorescence detection (FLD) or MS/MS are the most used for mycotoxin analysis [74-81]. In most cases, methods are validated on a single matrix and do not meet the supervisory bodies' needs that require different mycotoxin limits for different matrices $[67,77,78,82]$. Regarding extraction method, solid-phase extraction (SPE), solid-liquid extraction (SLE), and liquid-liquid extraction (LLE) are common techniques used for LC-MS/MS analysis and also for mycotoxin [74,82]. The challenge of mycotoxin analyses is that they have different proprieties and polarity [83]. Therefore the right choice of the extraction method can be difficult [84].

The QuEChERS (Quick Easy Cheap Effective Rugged and Safe) method is becoming one of the most used dispersive solid-phase extraction (d-SPE) methods in food safety [69,85-88]. According to Web of Science, more than 1200 scientific papers cover aspects or use QuEChERS for extraction procedures. The common steps of QuEChERS 
methods are LLE between an organic and an inorganic phase, addition of salts, agitation of the sample, removal of the supernatant, and d-SPE between supernatant and sorbents [89]. Competent authorities already use QuEChERS extraction to analyze various molecules such as pesticides and antibiotics $[90,91]$.

Multiclass multi-residue methods (MRMs) with QuEChERS d-SPE are preferred over other cleanup solutions requiring numerous steps and cost more time. Fast cleanup reduces the costs, time, and space required with solid-phase cartridges [92].

$\mathrm{QuEChERS}$ does not require high solvents volume and can be performed with basic laboratory devices [93] and with an extraction procedure that allows for the analysis of 20-30 samples in $1 \mathrm{~h}$.

The majority of methods are focused on increasing mycotoxins analyzed in a single matrix [94-97], especially in maize and in wheat [98].There are already QuEChERS mycotoxin procedures in the literature [99-101]. However, they are validated in a single matrix or use high-resolution mass spectrometry (HRMS), which is more expensive than an LC-MS/MS.

The present work aimed to validate QuEChERS extraction together with a fast and reliable LC-MS/MS method to detect 12 mycotoxins in cereals and 5 mycotoxins in black pepper, following the (EC) Regulation limits 1881/2006 and (EC) Regulation 401/2006.

\section{Materials and Methods}

\subsection{Chemical and Standards}

Methanol, acetonitrile, and formic acid were LC-MS-grades (>99.9\%), and were purchased from Sigma-Aldrich (Amsterdam, Holland). Ultrapure water was obtained in the laboratory using a Milli-Q system (Millipore Burlington, MA, USA). OTA, ZEA, DON, $\mathrm{AFB}_{1}, \mathrm{AFB}_{2}, \mathrm{AFG}_{1}, \mathrm{AFG}_{2}, \mathrm{FB}_{1}, \mathrm{FB}_{2}, \mathrm{FB}_{3}, \mathrm{~T} 2$, and $\mathrm{HT} 2$ were purchased by Sigma-Aldrich.

\subsection{Materials}

The products Supel QuE Citrate (EN) Tube (55227-U) and Supel QuE PSA (primary, secondary amine, EN) Tube (55228-U) were purchased from Sigma-Aldrich (Amsterdam Holland). The composition of $55227-\mathrm{U}$ is $4 \mathrm{~g} \mathrm{MgSO}_{4}, 1 \mathrm{~g} \mathrm{NaCl}, 0.5 \mathrm{~g}$ sodium citrate dibasic sesquihydrate, and $1 \mathrm{~g}$ sodium citrate tribasic dihydrate. $55228-\mathrm{U}$ contains $0.9 \mathrm{~g} \mathrm{MgSO}_{4}$ and $150 \mathrm{mg}$ of Supelclean PSA.

\subsection{Working Solutions}

Standards were mixed to obtain the following working solution: OTA, AFLA ( $\mathrm{AFB}_{1}$, $\left.\mathrm{AFB}_{2}, \mathrm{AFG}_{1}, \mathrm{AFG}_{2}\right), \mathrm{FUMO}\left(\mathrm{FB}_{1}, \mathrm{FB}_{2}, \mathrm{FB}_{3}\right), \mathrm{ZEA}, \mathrm{DON}$, MIX T2 (T2, HT2). Acetonitrile was used as solvent, except for SMix1 (low level) and Smix2 (high level), where methanol was used as solvent. A working solution was used to fortify the blank matrix sample, and low level and high level were used as calibration solutions (Table 1).

\subsection{Sample Preparation}

The method was applied to screen mycotoxins in Sicily (Southern Italy). About $10 \mathrm{~kg}$ of maize and $5 \mathrm{~kg}$ of black pepper were collected from 2 different local vendors in Palermo (Sicily) and used for validation procedures. Samples were grounded using a Mixer B-400 laboratory mill by BÜCHI (Cornaredo, Italy) at ambient temperature with knives' rotation speed of $9000 \mathrm{rpm}$. Samples grounded were stored at $-10^{\circ} \mathrm{C}$ until analysis.

\subsection{Sample Extraction}

About $5.0 \pm 0.1 \mathrm{~g}$ of the sample was weighted in a falcon tube of $50 \mathrm{~mL}$. A total of $150 \mu \mathrm{L}$ of OTA-d5 with a concentration of $100 \mu \mathrm{g} / \mathrm{L}$ was added to all samples $(3.0 \mu \mathrm{g} / \mathrm{Kg}$, $7.5 \mu \mathrm{g} / \mathrm{L}$ ). One sample for each matrix was fortified with the working solution as described above (Table 1). After 10 minutes, $10 \mathrm{~mL}$ of bidistilled water and $10 \mathrm{~mL}$ of an acetonitrile/formic acid solution $(80: 20 \mathrm{v} / \mathrm{v})$ were added to the sample. The sample was vortexed for $15 \mathrm{~min}$ and left to rest for 15 minutes at $-20{ }^{\circ} \mathrm{C}$. A mixture of salt $\left(4 \mathrm{~g} \mathrm{MgSO}_{4}, 1 \mathrm{~g}\right.$ 
$\mathrm{NaCl}, 0.5 \mathrm{~g}$ sodium citrate dibasic sesquihydrate, $1 \mathrm{~g}$ sodium citrate tribasic dihydrate) was added, handle shacking occurred for about 1 minute, and the mixture was centrifugated for $10 \mathrm{~min}$ at $5000 \mathrm{rpm}$. The supernatant was transferred into a mix of salt, $900 \mathrm{mg}$ $\mathrm{MgSO}_{4}$, and $150 \mathrm{mg}$ Supelclean PSA. After 1 minute of handle shacking and 5 minutes of centrifugationat $5000 \mathrm{rpm}, 3 \mathrm{~mL}$ of the supernatant was evaporated $\left(40^{\circ} \mathrm{C}\right)$ and dissolved in $600 \mu \mathrm{L}$ of methanol/water $(50 / 50 \mathrm{v} / \mathrm{v})$. The sample was ready for the injection.

Table 1. Working solutions were obtained by mixing standard solutions. Conc: concentration, BMF: blank matrix fortified, Vol: volume $(\mu \mathrm{L})$.

\begin{tabular}{|c|c|c|c|c|c|c|c|c|}
\hline \multirow[t]{2}{*}{$\begin{array}{l}\text { Working } \\
\text { Solutions }\end{array}$} & & \multirow[t]{2}{*}{ Conc. } & \multicolumn{2}{|c|}{ Fortified Sample } & \multicolumn{2}{|c|}{$\begin{array}{l}\text { SMix } 1 \text { (Low } \\
\text { Level) }\end{array}$} & \multicolumn{2}{|c|}{$\begin{array}{l}\text { SMix } 2 \text { (High } \\
\text { Level) }\end{array}$} \\
\hline & & & $\begin{array}{c}\text { Conc } \\
\mu \mathrm{g} / \mathrm{Kg} \\
(\mu \mathrm{g} / \mathrm{L})\end{array}$ & $\begin{array}{l}\text { Vol }^{2} \\
(\mu \mathrm{L})\end{array}$ & Conc. & $\begin{array}{l}\text { Vol }^{3} \\
(\mu \mathrm{L})\end{array}$ & $\mu \mathrm{g} / \mathrm{L}$ & $\begin{array}{l}\text { Vol }^{3} \\
(\mu L)\end{array}$ \\
\hline OTA & OTA & 100 & $3.0(7.5)$ & 150 & 1.5 & 15 & 7.5 & 75 \\
\hline \multirow[t]{4}{*}{ AFLA } & $\mathrm{AFB}_{1}$ & 100 & $1.6(4.0)$ & & 0.8 & & 4 & \\
\hline & $\mathrm{AFG}_{1}$ & 100 & $1.6(4.0)$ & 80 & 0.8 & 8 & 4 & 40 \\
\hline & $\mathrm{AFB}_{2}$ & 25 & $0.4(1.0)$ & & 0.2 & & 1 & \\
\hline & $\mathrm{AFG}_{2}$ & 25 & $0.4(1.0)$ & & 0.2 & & 1 & \\
\hline ZEA & ZEA & 1000 & 75 (187.5) & 375 & 37.5 & 37.5 & 187.5 & 187.5 \\
\hline \multirow[t]{3}{*}{ FUMO } & $\mathrm{FB}_{1}$ & 10,000 & $400(1000)$ & & 200 & & & \\
\hline & $\mathrm{FB}_{2}$ & 10,000 & $400(1000)$ & 200 & 200 & 20 & 1000 & 100 \\
\hline & $\mathrm{FB}_{3}$ & 10,000 & $400(1000)$ & & 200 & & & \\
\hline DON & DON & 10,000 & $100(250)$ & 50 & 50 & 5 & 250 & 25 \\
\hline \multirow[t]{3}{*}{ MIX T2 } & $\mathrm{T} 2$ & 1000 & $25(62.5)$ & & 12.5 & & & \\
\hline & & & & 125 & & 12.5 & 62.5 & 62.5 \\
\hline & HT2 & 1000 & $25(62.5)$ & & 12.5 & & & \\
\hline OTA-d $5^{1}$ & OTA D5 & 100 & $3.0(7.5)$ & 150 & 7.5 & 75 & 7.5 & 75 \\
\hline
\end{tabular}

${ }^{1}$ Internal standard. ${ }^{2}$ Volume of working solution to add to the fortified samples. ${ }^{3}$ Volume of working solution added to obtain $1 \mathrm{~mL}$ of SMix 1 (low level) and $1 \mathrm{~mL}$ of SMix2 (high level).

\subsection{Instrumentation}

The analysis was performed on a Thermo Fischer Ultra High Performance Liquid Chromatography(UHPLC ) system (Thermo Fisher Scientific, California, CA, USA) consisting of an ACCELA 1250 quaternary pump and an ACCELA autosampler. A Thermo Scientific Hypersil Gold reversed-phase UHPLC column (50 mm, $2.1 \mathrm{~mm}$ ID, $1.9 \mu \mathrm{m}$ ) was used for mycotoxin analysis.

The mobile phase (Table 2) was a time-programmed gradient using water (eluent A) and methanol (eluent $\mathrm{B}$ ). Both contained $2.50 \mathrm{mM}$ of ammonium formate and $0.1 \%$ formic acid. The chromatographic run started with $100 \%$ of A with a variation of $20 \%$ in $0.5 \mathrm{~min}$. The conditions were maintained for $1 \mathrm{~min}$, and then A decreased until a percentage of $40 \%$ in $0.1 \mathrm{~min}$. Linear decrease of A occurred with a total percentage of $B$ of $100 \%$ in $2.6 \mathrm{~min}$. Conditions were maintained for $0.7 \mathrm{~min}$, and the system returned to $100 \% \mathrm{~A}$ and $0 \%$ of $\mathrm{B}$ in $0.1 \mathrm{~min}$ for $1 \mathrm{~min}$.

Table 2. The mobile phases in the chromatography run.

\begin{tabular}{ccc}
\hline Time (min) & A (\%) & B (\%) \\
\hline 0 & 100 & 0 \\
0.5 & 80 & 20 \\
1.5 & 80 & 20 \\
1.6 & 40 & 60 \\
4.2 & 0 & 100 \\
4.9 & 0 & 100 \\
5 & 100 & 0 \\
6 & 100 & 0 \\
\hline
\end{tabular}

A triple quadrupole TSQ Vantage (Thermo Fisher Scientific, California, CA, USA) in positive electrospray ionization (ESI) mode was used as a spectrometer. The product 
ion scans were obtained by a direct infusion of each analyte dissolved in methanol/water $(50 / 50 \mathrm{v} / \mathrm{v})$.

The ESI parameters were set as follows: capillary temperature $310{ }^{\circ} \mathrm{C}$, vaporizer temperature $300{ }^{\circ} \mathrm{C}$, sheath gas pressure $40 \mathrm{psi}$, auxiliary gas pressure $30 \mathrm{psi}$, capillary voltage $4.8 \mathrm{kV}$. Collision gas, peak resolution, scan time, and scan width parameters were set as described in [102]. Trace Finder version 4.1 from Thermo Fisher (Kandel, Germany) was used to record and elaborate data. Results obtained from the analyte's direct infusion (parent, product 1, product 2, CE) and chromatography runs can be seen in Table 3 .

Table 3. Retention time, the most abundant $\mathrm{m} / \mathrm{z}$ ions and optimal collision energy (CE).

\begin{tabular}{ccccccc}
\hline Mycotoxin & Rt & Parent & Product 1 (m/z) & CE (V) & Product 2 (m/z) & CE (V) \\
\hline OTA & 3.52 & $404.2[\mathrm{M}+\mathrm{H}]^{+}$ & 239.2 & 27 & 221.7 & 37 \\
$\mathrm{ZEA}$ & 3.43 & $319.1[\mathrm{M}+\mathrm{H}]^{+}$ & 283.2 & 20 & 187.0 & 22 \\
$\mathrm{AFB}$ & 2.96 & $313.1[\mathrm{M}+\mathrm{H}]^{+}$ & 285.1 & 25 & 241.0 & 38 \\
$\mathrm{AFB}$ & 2.91 & $315.1[\mathrm{M}+\mathrm{H}]^{+}$ & 287.1 & 27 & 259.0 & 30 \\
$\mathrm{AFG}$ & 2.87 & $329.1[\mathrm{M}+\mathrm{H}]^{+}$ & 243.0 & 27 & 311.0 & 25 \\
$\mathrm{AFG}$ & 2.82 & $331.1[\mathrm{M}+\mathrm{H}]^{+}$ & 245.0 & 30 & 313.0 & 30 \\
$\mathrm{DON}$ & 1.04 & $297.2[\mathrm{M}+\mathrm{H}]^{+}$ & 203 & 20 & 249.2 & 15 \\
$\mathrm{FB}_{1}$ & 3.28 & $722.2[\mathrm{M}+\mathrm{H}]^{+}$ & 334.2 & 40 & 252.2 & 30 \\
$\mathrm{FB}_{2}$ & 3.45 & $706.3[\mathrm{M}+\mathrm{H}]^{+}$ & 354.2 & 37 & 336.1 & 37 \\
$\mathrm{FB}_{3}$ & 3.55 & $706.3[\mathrm{M}+\mathrm{H}]^{+}$ & 354.2 & 37 & 336.1 & 37 \\
$\mathrm{~T} 2$ & 3.32 & $484.2[\mathrm{M}+\mathrm{NH}]^{+}$ & 305.0 & 15 & 215.0 & 15 \\
$\mathrm{HT} 2$ & 3.17 & $442.2\left[\mathrm{M}+\mathrm{NH}_{4}\right]^{+}$ & 263.0 & 15 & 215.0 & 15 \\
\hline
\end{tabular}

\subsection{Validation Procedure}

The method was validated according to the EU Commission Decision 2002/657/EC, following the Council Directive 96/23/EC and Regulation (EC) no. 401/2006. Linearity, specificity, precision (repeatability and reproducibility within-laboratory), and ruggedness were determined. The specificity was determined by analyzing 20 blank and fortified samples for each matrix to assay the absence of interfering peaks. The linearity was tested with a standard curve of 5 points, including zero, as follows: $\mathrm{AFB}_{2}-\mathrm{AFG}_{2}(200-2000 \mu \mathrm{g} / \mathrm{L}), \mathrm{AFB}_{1}$ $\mathrm{AFG}_{2}(800-8000 \mu \mathrm{g} / \mathrm{L}), \mathrm{DON}(50,000-500,000 \mu \mathrm{g} / \mathrm{L}), \mathrm{FUMO}(200,000-2,000,000 \mu \mathrm{g} / \mathrm{L}), \mathrm{T} 2-$ HT2 $(125,00-125,000 \mu \mathrm{g} / \mathrm{L})$, ZEA $(37,500-375,000 \mu \mathrm{g} / \mathrm{L})$, OTA $(1500-15,000 \mu \mathrm{g} / \mathrm{L})$. The linear coefficients for each calibration in curve were $r^{2}>0.99$. The precision was assessed by fortifying 20 samples at screening target concentration (STC) and by analyzing 4 of them each day for 5 days to calculate intermediate precision (RSDRi); then, the cut-off was calculated. As required from Commission Regulation (EC) no. 401/2006, STC must be under or equal with MLs report into (EC) Regulation 1881/2006.

The ruggedness test was performed according to Youden [103] by determination of the effect of changing conditions (speed and time of centrifugation, time and speed of stirring, evaporation temperature). The identification of analytes was made by comparing the retention time in the sample $\left(\mathrm{TR}_{\mathrm{s}}\right)$ and the spiked sample $\left(\mathrm{TR}_{\mathrm{a}}\right)$ with a range of $\pm 0.1 \mathrm{~min}$.

The semi-quantification of analytes was made by extrapolation of data obtained in the linear regression between low level and high level (Table 1), and the concentration in the sample was obtained with the following formula:

$$
\mathrm{C}_{\mathrm{C}}=\mathrm{C}_{\mathrm{S}} \cdot \mathrm{D} \text {, }
$$

$\mathrm{C}_{\mathrm{c}}$ is the concentration in the matrix $(\mu \mathrm{g} / \mathrm{Kg}), \mathrm{C}_{\mathrm{s}}$ is solution $(\mu \mathrm{g} / \mathrm{L})$, and $\mathrm{D}$ is the dilution factor.

Matrix effect (MEs) in maize and spice were calculated as described by Juan Sun et al. [99]:

$$
\text { MEs }=100\left(1-\left(\mathrm{A}_{\mathrm{bm}} / \mathrm{A}_{\mathrm{s}}\right)\right)
$$

$\mathrm{A}_{\mathrm{bm}}$ is the area in the blank matrix and $\mathrm{A}_{\mathrm{s}}$ is the area of mycotoxin standard in solvent $(\mathrm{n}=3)$.

Accuracy was evaluated with the extraction of 20 fortified samples for each matrix. 


\subsection{Real Samples}

After validation, the method was tested with real samples collected during an inspection in Palermo (Sicily). Maize $(n=25)$ and wheat $(n=25)$ were collected from the same local vendors; black pepper $(n=25)$ and coffee $(n=25)$ were from two different local supermarkets in Palermo (Sicily). All samples were transported daily in the lab and, if needed, grounded as described in Section 2.4. The extractions were performed as described in Section 2.5.

\section{Results and Discussion}

\subsection{Method Development}

\subsubsection{Extraction Solvent and Cleanup}

The extraction method developed allows for extracting 12 mycotoxins in cereals and 5 in black pepper with a cheap and fast procedure. The best performance was attained using water and a mixture of acetonitrile/formic acid (80:20 v/v) Other ratios (60:40, 40:60, 20:80, 50:50) were examined to reach this conclusion (Figure 2). Acetonitrile and formic acid enhance analytical performance, as previously reported in the literature [104]. Acetonitrile/water extraction (in different percentages) is one of the most common mixtures used for mycotoxin analysis [105]. Acetonitrile can reduce the extraction of lipophilic materials such as fats and has a high capacity to extract molecules characterized by different polarities [106]. All mycotoxins analyzed are soluble in acetonitrile, and a higher percentage of acetonitrile can improve analytes' extraction. OTA, AFLA, and ZEA are soluble in polar organic solvents such as methanol and acetonitrile $[40,107,108]$. FUMO are hydrophilic mycotoxins (Figure 1) and are soluble in the same solvents and water [109].

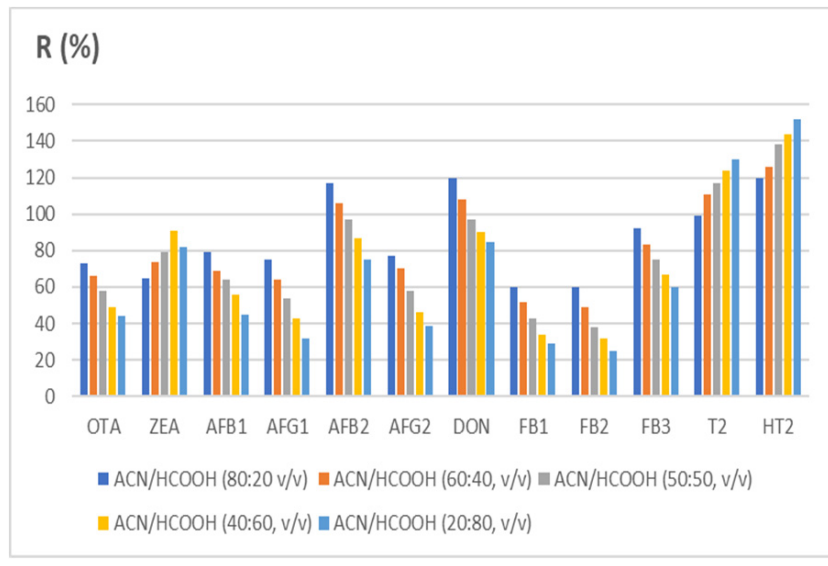

(a)

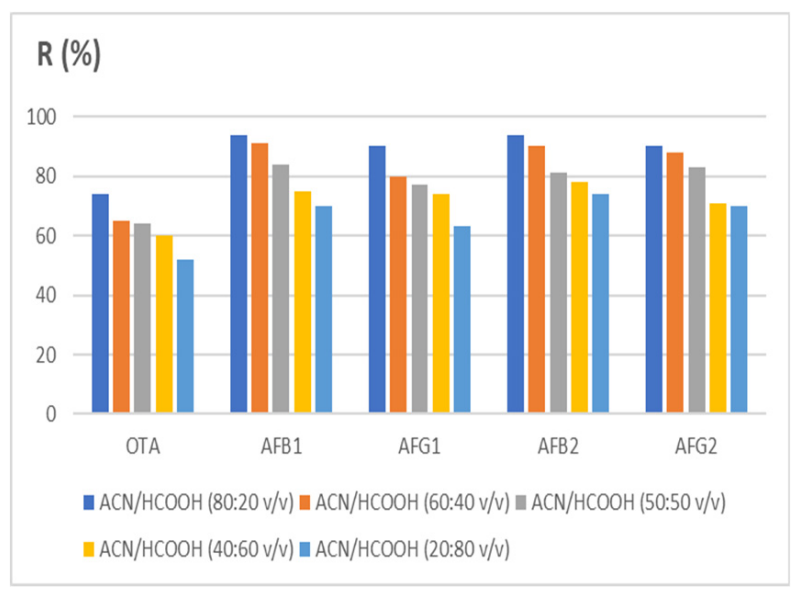

(b)

Figure 2. Effect of solvents on the extraction recovery: (a) maize; (b) black pepper. ACN, acetonitrile; $\mathrm{HCOOH}$, formic acid. The increase of ACN increased the recovery of all mycotoxins.

Regarding trichothecenes, T2, HT2, and DON are low soluble in water but highly soluble in ethanol and organic solvents [110]. For these reasons, acetonitrile, methanol, and water were used for the extraction procedure. Furthermore, water is added in high starch or low water matrices to reduce the interaction between them and analytes [111].

Formic acid and citrate salts decrease $\mathrm{pH}$ and contrast PSA's effect of increasing $\mathrm{pH}$ in the second step $[112,113] . \mathrm{MgSO}_{4}$ and $\mathrm{NaCl}$ increase the recovery of polar analytes, and $\mathrm{MSO}_{4}$ with PSA performs better and increases mycotoxins' recovery. [106,114].

The ratio between $\mathrm{MgSO}_{4}$ and PSA in the sorbent d-SPE step is always greater than 1 in all the literature, even if the quantity can change [106]. However, $900 \mathrm{MgSO}_{4}$ and $150 \mathrm{mg}$ of Supelclean PSA is already used in different analytical techniques that use QuEChERS methods for the extraction of analytes such as pesticides [115,116], likewise for the $4: 1 \mathrm{w} / \mathrm{w}$ ratio between $\mathrm{MgSO}_{4}$ and $\mathrm{NaCl}$ as salt added in the extraction procedure $[69,113,117,118]$. 


\subsubsection{Matrix Effect in Mycotoxin Analysis}

LC-MS/MS is susceptible to MEs, a common and unpredictable problem that can influence the validation process [119]. The ESI ionization is subject to ion suppression more than other atmospheric pressure ionization (API) techniques such as atmospheric pressure chemical ionization (APCI) [120].

Isotope-labeled internal standards can be useful to handle with MEs and are considered the "gold standard" approach [121]. This approach is useful for predicting the strong MEs in the analytical signal [122]. However, isotope-labeled internal standards are very expensive and do not exist for all mycotoxins, and recovery is not required in the screening method [123]. For these reasons, the use of a fortified sample for each analyte session seems more reasonable. Nevertheless, OTA-d5 was used in validation procedure and in real samples to evaluate the entire process.

In the present work, a strong ME was observed for AFLA with a range of $(+43.74$, $-20.18)$ in maize and $(-26.17,-0.89)$ in black pepper (Table 4$)$.

Table 4. Results of the validation procedure.

\begin{tabular}{|c|c|c|c|c|c|c|c|}
\hline Sample Type & Mycotoxin & $\begin{array}{l}\text { Linearity } \\
(\mu \mathrm{g} / \mathrm{L})\end{array}$ & $\begin{array}{c}\text { Matrix } \\
\text { Effect }(\%)\end{array}$ & $\begin{array}{c}\text { STC } \\
\mu \mathrm{g} / \mathrm{kg}\end{array}$ & $\begin{array}{c}\text { Cut-Off } \\
\mu \mathrm{g} / \mathrm{kg}\end{array}$ & $\begin{array}{l}\text { Repeat- } \\
\text { ability }\end{array}$ & $\begin{array}{c}\text { Recovery } \\
(\%)\end{array}$ \\
\hline \multirow[t]{12}{*}{ Maize } & OTA & $1.5-15$ & -25.40 & 3.0 & 0.93 & 1.81 & 73 \\
\hline & ZEA & $37.5-375$ & -2.85 & 75 & 43 & 7.83 & 65 \\
\hline & $\mathrm{AFB}_{1}$ & $0.8-8$ & -12.18 & 1.6 & 0.95 & 0.95 & 79 \\
\hline & $\mathrm{AFG}_{1}$ & $0.8-8$ & +43.74 & 1.6 & 1.06 & 0.19 & 75 \\
\hline & $\mathrm{AFB}_{2}$ & $0.20-2$ & -20.18 & 0.4 & 0.37 & 0.14 & 117 \\
\hline & $\mathrm{AFG}_{2}$ & $0.20-2$ & +6.69 & 0.4 & 0.27 & 0.057 & 77 \\
\hline & DON & $50-500$ & +37.06 & 100 & 75 & 36.7 & 120 \\
\hline & $\mathrm{FB}_{1}$ & 200-2000 & +57.26 & 400 & 75 & 36.7 & 60 \\
\hline & $\mathrm{FB}_{2}$ & 200-2000 & +66.82 & 400 & 46 & 141 & 60 \\
\hline & $\mathrm{FB}_{3}$ & 200-2000 & +21.47 & 400 & 212 & 223 & 92 \\
\hline & $\mathrm{T} 2$ & $12.50-125$ & -13.35 & 25 & 23 & 1.99 & 99 \\
\hline & HT2 & $12.50-125$ & -2.21 & 25 & 26 & 6.02 & 120 \\
\hline \multirow[t]{5}{*}{ Black pepper } & OTA & $1.5-15$ & -26.03 & 3.0 & 1.33 & 1.27 & 74 \\
\hline & $\mathrm{AFB}_{1}$ & $0.8-8$ & -13.64 & 1.6 & 1.44 & 0.09 & 94 \\
\hline & $\mathrm{AFG}_{1}$ & $0.8-8$ & -1.41 & 1.6 & 1.38 & 0.1 & 90 \\
\hline & $\mathrm{AFB}_{2}$ & $0.2-2$ & -26.17 & 0.4 & 0.35 & 0.03 & 94 \\
\hline & $\mathrm{AFG}_{2}$ & $0.2-2$ & -0.89 & 0.4 & 0.34 & 0.026 & 90 \\
\hline
\end{tabular}

MEs have been reported several times in the literature, but with discordant data, enhancing or suppressing black pepper [122,124,125] and maize [122]. FUMO was strongly enhanced with an overall increase of $48.51 \%$, as already reported by Beltrán et al. (2009) [104]. Curiously, OTA suppression in black pepper and maize was similar and had been reported before for maize [126].

The strong MEs in the mycotoxin analysis was caused by the lipid/water/protein content of matrices analyzed [127]. For these reasons, the analysis of different matrices should be validated according to (EC) no. 401/2006 that divides food into commodity groups to validate screening methods [67]. In this case, the research validated the commodity group of difficult or unique commodities (black pepper) that include cocoa beans and products thereof; copra and products thereof; coffee, tea, and licorice and the commodity group cereal grain and products thereof (maize), which include wheat, rye, barley, rice, oats, wholemeal bread, white bread, crackers, breakfast cereals, and pasta. Confirmatory methods must be validated in each matrix and for these reason screening methods, increasing the chance to discover new incidents and protect the consumers from high mycotoxin exposure [67].

\subsection{Method Optimization}

\subsubsection{Validation Parameters}

The analytical parameters of the methods used for mycotoxin analysis are regulated in Europe by the Commission Regulation (EC) no. 401/2006 that defines the criteria of 
analysis for the official control of the levels of mycotoxins in foodstuffs [128]. The analysis was performed under RSDRi, and all cut-off levels were under STC. The linear correlation of level tested in the range of linearity was acceptable $\left(r^{2}>0.99\right)$.

Regarding black pepper, maximum levels of OTA $(15 \mu \mathrm{g} / \mathrm{kg}), \mathrm{AFB}_{1}(5 \mu \mathrm{g} / \mathrm{kg})$, and the sum of $\mathrm{AFB}_{1}+\mathrm{AFB}_{2}+\mathrm{AFG}_{1}+\mathrm{AFG}_{2}(10 \mu \mathrm{g} / \mathrm{kg})$ were established from current legislation [67]. More mycotoxins are regulated for maize and unprocessed cereals intended for direct human consumption: OTA $(3 \mu \mathrm{g} / \mathrm{kg}), \mathrm{DON}(750 \mu \mathrm{g} / \mathrm{kg}), \mathrm{ZEA}(75 \mu \mathrm{g} / \mathrm{kg}), \mathrm{AFB}_{1}$ $(2 \mu \mathrm{g} / \mathrm{kg})$, the sum of $\mathrm{AFB}_{1}+\mathrm{AFB}_{2}+\mathrm{AFG}_{1}+\mathrm{AFG}_{2}(4 \mu \mathrm{g} / \mathrm{kg}), \mathrm{FB}_{1}+\mathrm{FB}_{2}(400 \mu \mathrm{g} / \mathrm{kg})$, and the sum of T2-HT2 $(3 \mu \mathrm{g} / \mathrm{kg})$. All mycotoxin listed were validated according to (EC) no. $401 / 2006$ regarding the screening method for mycotoxin analysis; the cut-off level must be equal or lower than the STC level, and the method developed was complied with. The validation data can be seen in Table 4 .

\subsubsection{Instrumental Method}

A cheap and simple screening method of 12 (cereal) and 5 (black pepper) mycotoxins was validated. Ammonium formate and formic acid were used to form ammonium adduct and protonated precursor ion, respectively. The ammonium adduct was selected as precursor ion only for T2 and HT2 (Table 3). All mycotoxins were detected within $4 \mathrm{~min}$. The adequate resolution was obtained between ions with the same $\mathrm{m} / \mathrm{z}$, which would be indistinguishable from the mass spectrometer if they coalesced. LC-MS/MS is used frequently to analyze molecules regulated by EU Legislation [129-132], and it is possible to perform semi-quantitative analysis [133]. For this reason, LC-MS/MS was preferred over other screening analytical techniques such as enzyme-linked immunosorbent assay (ELISA) [134,135].

Several parameters can influence the performance of mycotoxin analysis. Regarding instrument setting, the positive ion mode $\left(\mathrm{ESI}^{+}\right)$was chosen because there is a better response for the overall of mycotoxin $[104,127]$, especially AFLA that among mycotoxins are more regulated in the EU Legislation [67].

Water and methanol as mobile phases provided the best performance for peak resolution and run time for the chromatographic run. The same result was reported in the literature $[84,99,127]$. Ammonium acetate and formic acid addiction in the mobile phase increase the analytical performance $[94,104,136,137]$. The best results were achieved with $0.1 \%$ of formic acid and $2.5 \mathrm{mM}$ of $\mathrm{NH}_{4} \mathrm{COOH}$, as already reported by other authors [123].

With a total chromatography run of $6 \mathrm{~min}$ and an extraction procedure that takes approximately 1 hour, the method developed is faster than other methods already reported in the literature [138-142] and is useful for quick screening.

AFLA are not sensitive to heat treatment and can increase during the food storage period. A quick screening before storage can be useful to have some data on mycotoxins' presence $[48,143,144]$.

Black pepper is a less studied matrix, and increased data on mycotoxins presence can help in the risk assessment of mycotoxins exposure. This is especially the case because there is a possible co-occurrence of mycotoxin due to the multiple fungal infections [145] and because they are used as flavor-enhancers in convenience foods.

However, this result has not been reached without compromises. Masked mycotoxins such as 3-acetyl deoxynivalenol (3-AcDON) and 15-acetyl-deoxynivalenol (15-AcDON) that present different toxicities [146] are not currently regulated in EU Legislation and were not analyzed. Some peaks are moderately overlapped, such as for $\mathrm{FB}_{2}$ and $\mathrm{FB}_{3}$; however (EC) no. 1881/2006 requires only sum of $\mathrm{FB}_{1}+\mathrm{FB}_{2}$ (Figure 3). Ergot sclerotia and ergot alkaloids required from (EC) no. 1881/2006 were not analyzed. 


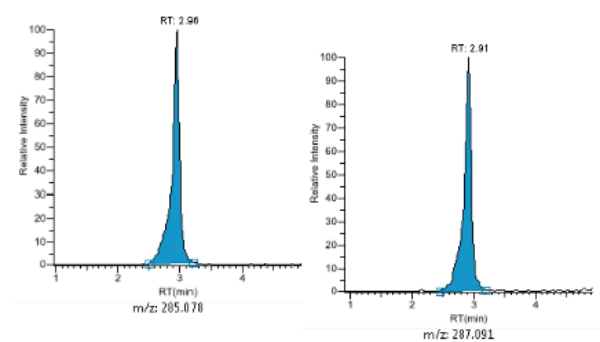

(a)
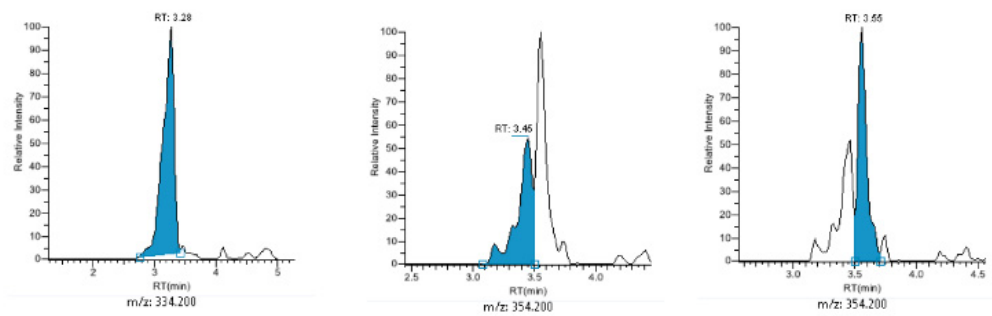

(c)
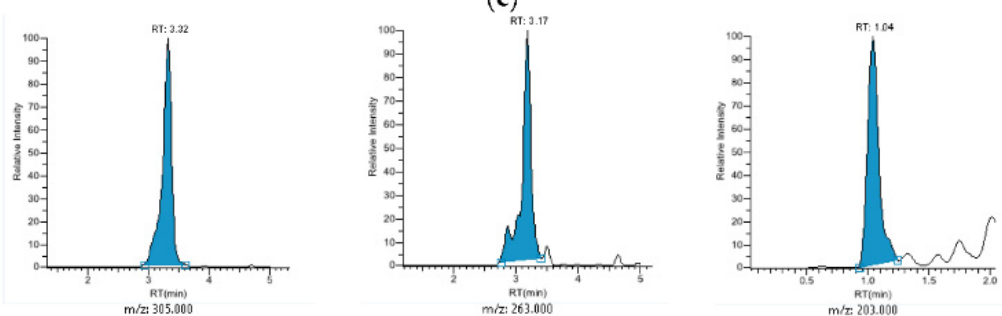

(d)
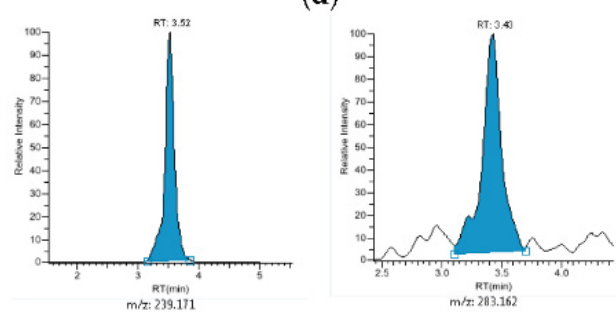

(e)

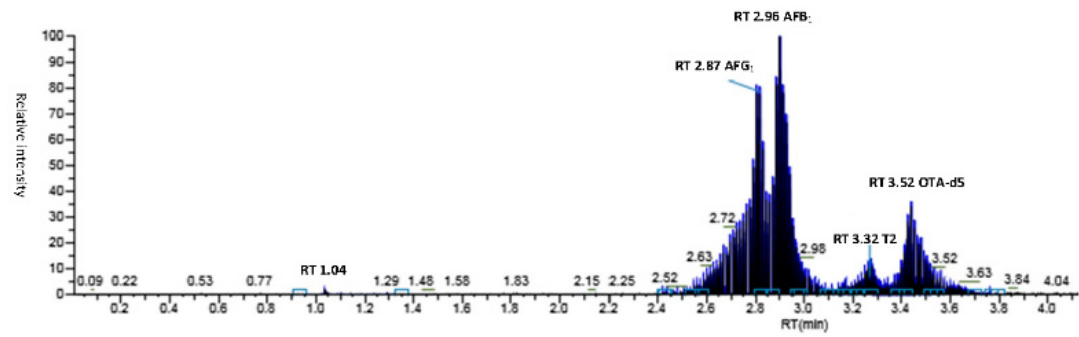

(f)

Figure 3. Ultra-high-performance liquid chromatography coupled with tandem mass spectrometry (UHPLC-MS/MS) chromatograms obtained from a blank maize spiked with working solution (Table 1). Fumonisins were spiked at $100 \mu \mathrm{g} / \mathrm{kg}$ for a better visualization. From left to right: (a) $\mathrm{AFB}_{1}, \mathrm{AFB}_{2}$; (b) $\mathrm{AFG}_{1}, \mathrm{AFG}_{2}$; (c) $\mathrm{FB}_{1}, \mathrm{FB}_{2}, \mathrm{FB}_{3}$; (d)T2, HT2, DON; (e) OTA, ZEA; (f) total ion chromatogram (TIC). 


\subsection{Ring Test and Application to Real Samples}

3.3.1. Ring Test

The laboratories' performance was assessed by proficiency tests (PTs) following ISO/IEC 17025:2018. The analytical quality of the validated method was assured by the participation in the interlaboratory study. The following PTs were purchased by Progetto Trieste (Test Veritas, Padova, Italy): MA2050 that consist of maize with an assigned values of $\mathrm{AFB}_{1}+, \mathrm{AFB}_{2}+, \mathrm{AFG}_{1}+, \mathrm{AFG}_{2}$ of $16.57 \mu \mathrm{g} / \mathrm{kg}$ expressed as sum; maize MA2051 with DON $702.14 \mu \mathrm{g} / \mathrm{kg}$; ZEA $232.61 \mu \mathrm{g} / \mathrm{kg}$; F2061 feed with $11.42 \mu \mathrm{g} / \mathrm{kg} \mathrm{AFB}{ }_{1} ; 2.42 \mu \mathrm{g} / \mathrm{kg}$ $\mathrm{AFB}_{2} ; 7.65 \mu \mathrm{g} / \mathrm{kg} \mathrm{AFG}$; wheat WH2062 with DON $527.05 \mu \mathrm{g} / \mathrm{kg}$ and T2 $18.31 \mu \mathrm{g} / \mathrm{kg}$; dried figs DF2064 with $\mathrm{AFB}_{1} 7.30 \mu \mathrm{g} / \mathrm{kg} ; \mathrm{AFG}_{1} 5.35 \mu \mathrm{g} / \mathrm{kg}$; and OTA $8.79 \mu \mathrm{g} / \mathrm{kg}$; and GC + C2053 that consists of coffee with an assigned value of $7.53 \mu \mathrm{g} / \mathrm{kg}$ for OTA (Progetto Trieste, Test Veritas, Padova, Italy). The results of all tests were compliant with ISO/IEC 17025:2018. It is worth noting that according to (EC) no. 401/2006, dried figs are classified as "high sugar and low water content", which is a commodity group not validated, and despite this, the result was compliant with ISO/IEC 17025:2018.

\subsubsection{Application of the Method to Real Samples}

All samples were compliant and following (EC) no. 1881/2006. One sample of maize resulted with OTA at $2.53 \mu \mathrm{g} / \mathrm{Kg}$, and one sample of black pepper resulted with 1.85 $\mu \mathrm{g} / \mathrm{Kg}$ of OTA and the contemporary presence of $0.358 \mu \mathrm{g} / \mathrm{Kg}$ of $\mathrm{AFB}_{2}$ (Table 5).

Table 5. Results of the analyses on real samples. A total of 25 samples were analyzed for each matrix. Dash indicates that all results were under cut-off levels.

\begin{tabular}{cccc}
\hline $\begin{array}{c}\text { Sample } \\
\text { Commodity }\end{array}$ & $\begin{array}{c}\text { Detected } \\
\text { Mycotoxin }\end{array}$ & $\begin{array}{c}\text { Number of Sample with a } \\
\text { Detectable Amount of Mycotoxin }\end{array}$ & Amount \\
\hline Maize & OTA & 1 & $2.53 \mu \mathrm{g} / \mathrm{kg}$ \\
Wheat & - & 0 & - \\
Black pepper & $\mathrm{OTA}^{-}$ & 1 & $1.85 \mu \mathrm{g} / \mathrm{kg}$ \\
Coffee & $\mathrm{AFB}_{2}$ & 1 & $0.358 \mu \mathrm{g} / \mathrm{kg}$ \\
\hline
\end{tabular}

\section{Conclusions}

A new method for detecting 12 mycotoxins in cereals and 5 mycotoxins in spices (black pepper) was developed and validated according to (EC) no. 401/2006. QuEChERS extraction was used effectively. The best performances were obtained with acetonitrile/formic acid $(80: 20 \mathrm{v} / \mathrm{v})$ as extraction solvent. Strong MEs were observed in all the FUMO analyzed in maize, while AFLA had enhancing or suppressing effects. In black pepper, there was a suppression of signals for all mycotoxins analyzed. Six PTs were developed to evaluate the performance of the method. The method was applied to 100 real samples ( 25 maize, 25 wheat, 25 black pepper, and 25 coffee). Two samples had a detectable amount of mycotoxin, maize (OTA, $2.53 \mu \mathrm{g} / \mathrm{Kg}$ ), and black pepper (OTA, $1.85 \mu \mathrm{g} / \mathrm{Kg}$, and $\mathrm{AFB}_{2}, 0.358 \mu \mathrm{g} / \mathrm{Kg}$ ). The method proposed is suitable for screening and routine analysis to monitor mycotoxins content in foodstuff following European Regulamentation. Further studies are needed to increase the number of mycotoxins analyzed and increase commodity groups analyzed with the same method.

Author Contributions: Conceptualization, L.P. and F.O.; methodology L.P., M.D.B., and L.L.S.; validation L.P. and M.D.B.; formal analysis, F.O. and C.B.; writing—original draft preparation, F.G.G. and L.P.; writing - review and editing F.G.G. and L.P.; supervision, A.V. and A.M.; project administration, A.M. and A.V. All authors have read and agreed to the published version of the manuscript.

Funding: This research received no external funding.

Institutional Review Board Statement: Not applicable

Informed Consent Statement: Not applicable 


\section{Data Availability Statement: Not applicable}

Conflicts of Interest: The authors declare no conflict of interest.

\section{References}

1. Bennett, J.W.; Klich, M. Mycotoxins. Clin. Microbiol. Rev. 2003, 16, 497-516. [CrossRef] [PubMed]

2. Goodman, L.S. Goodman and Gilman's Manual of Pharmacology and Therapeutics; McGraw Hill Professional: New York, NY, USA, 2008; ISBN 978-0-07-144343-2.

3. Fung, F.; Clark, R.F. Health Effects of Mycotoxins: A Toxicological Overview. J. Toxicol. Clin. Toxicol. 2004, 42, 217-234. [CrossRef] [PubMed]

4. Speijers, G.J.A.; Speijers, M.H.M. Combined Toxic Effects of Mycotoxins. Toxicol. Lett. 2004, 153, 91-98. [CrossRef] [PubMed]

5. Adhikari, M.; Negi, B.; Kaushik, N.; Adhikari, A.; Al-Khedhairy, A.A.; Kaushik, N.K.; Choi, E.H. T-2 Mycotoxin: Toxicological Effects and Decontamination Strategies. Oncotarget 2017, 8, 33933-33952. [CrossRef] [PubMed]

6. Peraica, M.; Radić, B.; Lucić, A.; Pavlović, M. Toxic Effects of Mycotoxins in Humans. Bull. World Health Organ. 1999, 77, 754-766. [PubMed]

7. Abd-Elsalam, K.A.; Rai, M. Chapter 1-An introduction to nanomycotoxicology. In Nanomycotoxicology; Rai, M., Abd-Elsalam, K.A., Eds.; Academic Press: Cambridge, MA, USA, 2020; pp. 1-7. ISBN 978-0-12-817998-7.

8. Agriopoulou, S.; Stamatelopoulou, E.; Varzakas, T. Advances in Occurrence, Importance, and Mycotoxin Control Strategies: Prevention and Detoxification in Foods. Foods 2020, 9, 137. [CrossRef]

9. Klich, M.A. Aspergillus Flavus: The Major Producer of Aflatoxin. Mol. Plant. Pathol. 2007, 8, 713-722. [CrossRef]

10. Smith, J.W.; Groopman, J.D. Aflatoxins. In Encyclopedia of Cancer, 3rd ed.; Boffetta, P., Hainaut, P., Eds.; Academic Press: Oxford, UK, 2019; pp. 30-43. ISBN 978-0-12-812485-7.

11. Bräse, S.; Gläser, F.; Kramer, C.; Lindner, S.; Linsenmeier, A.M.; Masters, K.-S.; Meister, A.C.; Ruff, B.M.; Zhong, S. The Chemistry of Mycotoxins; Progress in the Chemistry of Organic Natural Products; Springer: Vienna, Austria, 2013; Volume 97, ISBN 978-3-7091-1311-0.

12. Guevara-González, R.G. Aflatoxins_Biochemistry and Molecular Biology; INTECH Open Access Publisher: London, UK, 2011; ISBN 978-953-307-395-8.

13. Alshannaq, A.; Yu, J.-H. Occurrence, Toxicity, and Analysis of Major Mycotoxins in Food. Int. J. Environ. Res. Public Health 2017, 14, 632. [CrossRef]

14. Benkerroum, N. Chronic and Acute Toxicities of Aflatoxins: Mechanisms of Action. Int. J. Environ. Res. Public Health 2020, 17, 423. [CrossRef]

15. International Agency for Research on Cancer (Ed.) Some Traditional Herbal Medicines, Some Mycotoxins, Naphthalene and Styrene: This Publication Represents the Views and Expert Opinions of an IARC Working Group on the Evaluation of Carcinogenic Risks to Humans, Which Met in Lyon, 12-19 February 2002; IARC monographs on the evaluation of carcinogenic risks to humans; IARC: Lyon, France, 2002; ISBN 978-92-832-1282-9.

16. Guengerich, F.P.; Johnson, W.W.; Ueng, Y.-F.; Yamazaki, H.; Shimada, T. Involvement of Cytochrome P450, Glutathione STransferase, and Epoxide Hydrolase in the Metabolism of Aflatoxin B1 and Relevance to Risk of Human Liver Cancer. Environ. Health Perspect. 1996, 104, 557-562. [CrossRef]

17. Groopman, J.D.; Cain, L.G.; Kensler, T.W. Aflatoxin Exposure in Human Populations: Measurements and Relationship to Cancer. Crit. Rev. Toxicol. 1988, 19, 113-145. [CrossRef] [PubMed]

18. Faulkner, A.G. (Ed.) Aflatoxins: Food Sources, Occurrence and Toxicological Effects; Food science and technology; Nova Publishers: New York, NY, USA, 2014; ISBN 978-1-63117-514-5.

19. Rheeder, J.P.; Marasas, W.F.O.; Vismer, H.F. Production of Fumonisin Analogs by Fusarium Species. Appl. Environ. Microbiol. 2002, 68, 2101-2105. [CrossRef] [PubMed]

20. Arumugam, T.; Ghazi, T.; Chuturgoon, A. Fumonisin B1 Epigenetically Regulates PTEN Expression and Modulates DNA Damage Checkpoint Regulation in HepG2 Liver Cells. Toxins 2020, 12, 625. [CrossRef] [PubMed]

21. Waśkiewicz, A.; Beszterda, M.; Goliński, P. Occurrence of Fumonisins in Food-An Interdisciplinary Approach to the Problem. Food Control. 2012, 26, 491-499. [CrossRef]

22. Qian, G.; Tang, L.; Lin, S.; Xue, K.S.; Mitchell, N.J.; Su, J.; Gelderblom, W.C.; Riley, R.T.; Phillips, T.D.; Wang, J.-S. Sequential Dietary Exposure to Aflatoxin B1 and Fumonisin B1 in F344 Rats Increases Liver Preneoplastic Changes Indicative of a Synergistic Interaction. Food Chem. Toxicol. 2016, 95, 188-195. [CrossRef]

23. Maiorano, A.; Blandino, M.; Reyneri, A.; Vanara, F. Effects of Maize Residues on the Fusarium Spp. Infection and Deoxynivalenol (DON) Contamination of Wheat Grain. Crop. Prot. 2008, 27, 182-188. [CrossRef]

24. Sobrova, P.; Adam, V.; Vasatkova, A.; Beklova, M.; Zeman, L.; Kizek, R. Deoxynivalenol and Its Toxicity. Interdiscip. Toxicol. 2010, 3, 94-99. [CrossRef] [PubMed]

25. Vesonder, R.F.; Ciegler, A.; Jensen, A.H. Isolation of the Emetic Principle from Fusarium-Infected Corn. Appl. Microbiol. 1973, 26, 1008-1010. [CrossRef]

26. Bonnet, M.S.; Roux, J.; Mounien, L.; Dallaporta, M.; Troadec, J.-D. Advances in Deoxynivalenol Toxicity Mechanisms: The Brain as a Target. Toxins 2012, 4, 1120-1138. [CrossRef] 
27. Zhao, X.; Li, R.; Zhou, C.; Zhang, J.; He, C.; Zheng, Y.; Wu, W.; Zhang, H. Separation and Purification of Deoxynivalenol (DON) Mycotoxin from Wheat Culture Using a Simple Two-Step Silica Gel Column Chromatography. J. Integr. Agric. 2016, 15, 694-701. [CrossRef]

28. Wolf-Hall, C.E.; Hanna, M.A.; Bullerman, L.B. Stability of Deoxynivalenol in Heat-Treated Foods. J. Food Prot. 1999, 62, 962-964. [CrossRef]

29. Haschek, W.M.; Voss, K.A. Chapter 39-Mycotoxins. In Haschek and Rousseaux's Handbook of Toxicologic Pathology, 3rd ed.; Haschek, W.M., Rousseaux, C.G., Wallig, M.A., Eds.; Academic Press: Boston, MA, USA, 2013; pp. 1187-1258. ISBN 978-0-12-415759-0.

30. McCormick, S.P.; Stanley, A.M.; Stover, N.A.; Alexander, N.J. Trichothecenes: From Simple to Complex Mycotoxins. Toxins 2011, 3, 802-814. [CrossRef]

31. Sudakin, D.L. Trichothecenes in the Environment: Relevance to Human Health. Toxicol. Lett. 2003, 143, 97-107. [CrossRef]

32. Scientific Opinion on the Risks for Animal and Public Health Related to the Presence of T-2 and HT-2 Toxin in Food and Feed. EFSA J. 2011, 9, 2481. [CrossRef]

33. Palumbo, R.; Crisci, A.; Venâncio, A.; Cortiñas Abrahantes, J.; Dorne, J.-L.; Battilani, P.; Toscano, P. Occurrence and Co-Occurrence of Mycotoxins in Cereal-Based Feed and Food. Microorganisms 2020, 8, 74. [CrossRef] [PubMed]

34. Bullerman, L.B. Mycotoxins I Classifications. In Encyclopedia of Food Sciences and Nutrition, 2nd ed.; Caballero, B., Ed.; Academic Press: Oxford, UK, 2003; pp. 4080-4089. ISBN 978-0-12-227055-0.

35. Li, Y.; Wang, Z.; Beier, R.C.; Shen, J.; Smet, D.D.; De Saeger, S.; Zhang, S. T-2 Toxin, a Trichothecene Mycotoxin: Review of Toxicity, Metabolism, and Analytical Methods. J. Agric. Food Chem. 2011, 59, 3441-3453. [CrossRef] [PubMed]

36. Heussner, A.H.; Bingle, L.E.H. Comparative Ochratoxin Toxicity: A Review of the Available Data. Toxins 2015, 7, 4253-4282. [CrossRef]

37. Gupta, R.C. (Ed.) Veterinary Toxicology: Basic and Clinical Principles, 3rd ed.; Academic Press: Amsterdam, The Netherlands, 2018; ISBN 978-0-12-811410-0.

38. Risk Assessment of Ochratoxin A in Food-2020-EFSA Journal-Wiley Online Library. Available online: https://efsa. onlinelibrary.wiley.com/doi/10.2903/j.efsa.2020.6113 (accessed on 7 March 2021).

39. Piacentini, K.C.; Ferranti, L.S.; Pinheiro, M.; Bertozzi, B.G.; Rocha, L.O. Mycotoxin Contamination in Cereal-Based Baby Foods. Curr. Opin. Food Sci. 2019, 30, 73-78. [CrossRef]

40. El Khoury, A.; Atoui, A. Ochratoxin A: General Overview and Actual Molecular Status. Toxins 2010, 2, 461-493. [CrossRef] [PubMed]

41. Zhang, G.-L.; Feng, Y.-L.; Song, J.-L.; Zhou, X.-S. Zearalenone: A Mycotoxin with Different Toxic Effect in Domestic and Laboratory Animals' Granulosa Cells. Front. Genet. 2018, 9. [CrossRef] [PubMed]

42. Scientific Opinion on the Risks for Public Health Related to the Presence of Zearalenone in Food. EFSA J. 2011, 9, 2197. [CrossRef]

43. Schöneberg, T.; Kibler, K.; Wettstein, F.E.; Bucheli, T.D.; Forrer, H.R.; Musa, T.; Mascher, F.; Bertossa, M.; Keller, B.; Vogelgsang, S. Influence of Temperature, Humidity Duration and Growth Stage on the Infection and Mycotoxin Production by Fusarium Langsethiae and Fusarium Poae in Oats. Plant. Pathol. 2019, 68, 173-184. [CrossRef]

44. Felizardo, R.J.; Câmara, N.O. Hepatocellular Carcinoma and Food Contamination: Aflatoxins and Ochratoxin A as Great Prompter. World J. Gastroenterol. 2013, 19, 3723-3725. [CrossRef] [PubMed]

45. Haque, M.A.; Wang, Y.; Shen, Z.; Li, X.; Saleemi, M.K.; He, C. Mycotoxin Contamination and Control Strategy in Human, Domestic Animal and Poultry: A Review. Microb. Pathog. 2020, 142, 104095. [CrossRef] [PubMed]

46. Paterson, R.R.M.; Lima, N. How Will Climate Change Affect Mycotoxins in Food? Food Res. Int. 2010, 43, 1902-1914. [CrossRef]

47. Calado, T.; Venâncio, A.; Abrunhosa, L. Irradiation for Mold and Mycotoxin Control: A Review. Compr. Rev. Food Sci. Food Saf. 2014, 13, 1049-1061. [CrossRef]

48. Scott, P.M. Effects of Food Processing on Mycotoxins. J. Food Prot. 1984, 47, 489-499. [CrossRef]

49. Houbraken, J.; Samson, R.A.; Frisvad, J.C. Byssochlamys: Significance of Heat Resistance and Mycotoxin Production. In Proceedings of the Advances in Food Mycology; Hocking, A.D., Pitt, J.I., Samson, R.A., Thrane, U., Eds.; Springer US: Boston, MA, USA, 2006; pp. 211-224.

50. Obonyo, M.A.; Salano, E.N. Perennial and Seasonal Contamination of Maize by Aflatoxins in Eastern Kenya. Food Contam. 2018, 5, 6. [CrossRef] [PubMed]

51. Pitt, J.I. Toxigenic Fungi and Mycotoxins. Br. Med. Bull. 2000, 56, 184-192. [CrossRef] [PubMed]

52. Coppa, C.F.S.C.; Cirelli, A.C.; Gonçalves, B.L.; Barnabé, E.M.B.; Mousavi Khaneghah, A.; Corassin, C.H.; Oliveira, C.A.F. Dietary Exposure Assessment and Risk Characterization of Mycotoxins in Lactating Women: Case Study of São Paulo State, Brazil. Food Res. Int. 2020, 134, 109272. [CrossRef]

53. Vin, K.; Rivière, G.; Leconte, S.; Cravedi, J.-P.; Fremy, J.M.; Oswald, I.P.; Roudot, A.-C.; Vasseur, P.; Jean, J.; Hulin, M.; et al. Dietary Exposure to Mycotoxins in the French Infant Total Diet Study. Food Chem. Toxicol. 2020, 140, 111301. [CrossRef]

54. Gracia-Lor, E.; Zuccato, E.; Hernández, F.; Castiglioni, S. Wastewater-Based Epidemiology for Tracking Human Exposure to Mycotoxins. J. Hazard. Mater. 2020, 382, 121108. [CrossRef] [PubMed]

55. Tonon, K.M.; Reiter, M.G.R.; de Oliveira Dutra, M.; Savi, G.D.; Scussel, V.M. Dietary Intake of Mycotoxin Susceptible Foods by Brazilian Nursing Mothers. Curr. Nutr. Food Sci. 2020, 16, 953-962. [CrossRef]

56. Han, Z.; Nie, D.; Yang, X.; Wang, J.; Peng, S.; Wu, A. Quantitative Assessment of Risk Associated with Dietary Intake of Mycotoxin Ochratoxin A on the Adult Inhabitants in Shanghai City of P.R. China. Food Control. 2013, 32, 490-495. [CrossRef] 
57. Przybyłowicz, K.E.; Arłukowicz, T.; Danielewicz, A.; Morze, J.; Gajęcka, M.; Zielonka, Ł.; Fotschki, B.; Sawicki, T. Association between Mycotoxin Exposure and Dietary Habits in Colorectal Cancer Development Among a Polish Population: A Study Protocol. Int. J. Environ. Res. Public Health 2020, 17, 698. [CrossRef] [PubMed]

58. Misihairabgwi, J.M.; Ezekiel, C.N.; Sulyok, M.; Shephard, G.S.; Krska, R. Mycotoxin Contamination of Foods in Southern Africa: A 10-Year Review (2007-2016). Crit. Rev. Food Sci. Nutr. 2019, 59, 43-58. [CrossRef] [PubMed]

59. Cammilleri, G.; Graci, S.; Collura, R.; Buscemi, M.D.; Vella, A.; Macaluso, A.; Giaccone, V.; Giangrosso, G.; Cicero, A.; Lo Dico, G.M.; et al. Aflatoxin M1 in Cow, Sheep, and Donkey Milk Produced in Sicily, Southern Italy. Mycotoxin Res. 2019, 35, 47-53. [CrossRef] [PubMed]

60. Zinedine, A.; Brera, C.; Elakhdari, S.; Catano, C.; Debegnach, F.; Angelini, S.; De Santis, B.; Faid, M.; Benlemlih, M.; Minardi, V.; et al. Natural Occurrence of Mycotoxins in Cereals and Spices Commercialized in Morocco. Food Control. 2006, 17, 868-874. [CrossRef]

61. Sarmast, E.; Fallah, A.A.; Jafari, T.; Mousavi Khaneghah, A. Occurrence and Fate of Mycotoxins in Cereals and Cereal-Based Products: A Narrative Review of Systematic Reviews and Meta-Analyses Studies. Curr. Opin. Food Sci. 2021, 39, 68-75. [CrossRef]

62. Khaneghah, A.M.; Fakhri, Y.; Gahruie, H.H.; Niakousari, M.; Sant'Ana, A.S. Mycotoxins in Cereal-Based Products during 24 Years (1983-2017): A Global Systematic Review. Trends Food Sci. Technol. 2019, 91, 95-105. [CrossRef]

63. Animal Feed Contamination-1st Edition. Available online: https://www.elsevier.com/books/animal-feed-contamination/finkgremmels /978-1-84569-725-9 (accessed on 28 September 2020).

64. Martins, M.L.; Martins, H.M.; Bernardo, F. Aflatoxins in Spices Marketed in Portugal. Food Addit. Contam. 2001, 18, 315-319. [CrossRef] [PubMed]

65. Selim, M.I.; Popendorf, W.; Ibrahim, M.S.; Sharkawy, S.E.; Kashory, E.S.E. Anatoxin B1 in Common Egyptian Foods. J. AOAC Int. 1996, 79, 1124-1129. [CrossRef] [PubMed]

66. European Commission. Directorate-General for Health and Food Safety. In RASFF Annual Report 2019; European Commission: Brussels, Belgium, 2020; ISBN 978-92-76-17508-7.

67. EUR-Lex-02006R1881-20200701-EN_EUR-Lex. Available online: https:// eur-lex.europa.eu/legal-content/EN/TXT/?uri= CELEX\%3A02006R1881-20200701 (accessed on 23 July 2020).

68. Berthiller, F.; Crews, C.; Dall'Asta, C.; Saeger, S.D.; Haesaert, G.; Karlovsky, P.; Oswald, I.P.; Seefelder, W.; Speijers, G.; Stroka, J. Masked Mycotoxins: A Review. Mol. Nutr. Food Res. 2013, 57, 165-186. [CrossRef] [PubMed]

69. Cunha, S.C.; Fernandes, J.O. Development and Validation of a Method Based on a QuEChERS Procedure and Heart-Cutting GC-MS for Determination of Five Mycotoxins in Cereal Products. J. Sep. Sci. 2010, 33, 600-609. [CrossRef] [PubMed]

70. Rodríguez-Carrasco, Y.; Moltó, J.C.; Mañes, J.; Berrada, H. Exposure Assessment Approach through Mycotoxin/Creatinine Ratio Evaluation in Urine by GC-MS/MS. Food Chem. Toxicol. 2014, 72, 69-75. [CrossRef]

71. Rastogi, S.; Dwivedi, P.D.; Khanna, S.K.; Das, M. Detection of Aflatoxin M1 Contamination in Milk and Infant Milk Products from Indian Markets by ELISA. Food Control. 2004, 15, 287-290. [CrossRef]

72. Rubert, J.; Soler, C.; Mañes, J. Application of an HPLC-MS/MS Method for Mycotoxin Analysis in Commercial Baby Foods. Food Chem. 2012, 133, 176-183. [CrossRef]

73. Colombo, R.; Papetti, A. Pre-Concentration and Analysis of Mycotoxins in Food Samples by Capillary Electrophoresis. Molecules 2020, 25, 3441. [CrossRef]

74. Turner, N.; Subrahmanyam, S.; Piletsky, S. Analytical Methods for Determination of Mycotoxins: A Review. Anal. Chim. Acta 2009, 632, 168-180. [CrossRef]

75. Irakli, M.N.; Skendi, A.; Papageorgiou, M.D. HPLC-DAD-FLD Method for Simultaneous Determination of Mycotoxins in Wheat Bran. J. Chromatogr. Sci. 2017, 55, 690-696. [CrossRef]

76. Czerwiecki, L.; Wilczyńska, G. Determination of Deoxynivalenol in Cereals by HPLC-UV. Mycotoxin Res. 2003, 19, 31-34. [CrossRef]

77. Rasmussen, R.R.; Storm, I.M.L.D.; Rasmussen, P.H.; Smedsgaard, J.; Nielsen, K.F. Multi-Mycotoxin Analysis of Maize Silage by LC-MS/MS. Anal. Bioanal. Chem. 2010, 397, 765-776. [CrossRef] [PubMed]

78. Mavungu, J.D.D.; Monbaliu, S.; Scippo, M.-L.; Maghuin-Rogister, G.; Schneider, Y.-J.; Larondelle, Y.; Callebaut, A.; Robbens, J.; Peteghem, C.V.; Saeger, S.D. LC-MS/MS Multi-Analyte Method for Mycotoxin Determination in Food Supplements. Food Addit. Contam. Part. A 2009, 26, 885-895. [CrossRef] [PubMed]

79. Warth, B.; Parich, A.; Atehnkeng, J.; Bandyopadhyay, R.; Schuhmacher, R.; Sulyok, M.; Krska, R. Quantitation of Mycotoxins in Food and Feed from Burkina Faso and Mozambique Using a Modern LC-MS/MS Multitoxin Method. J. Agric. Food Chem. 2012, 60, 9352-9363. [CrossRef] [PubMed]

80. Njumbe Ediage, E.; Diana Di Mavungu, J.; Monbaliu, S.; Van Peteghem, C.; De Saeger, S. A Validated Multianalyte LC-MS/MS Method for Quantification of 25 Mycotoxins in Cassava Flour, Peanut Cake and Maize Samples. J. Agric. Food Chem. 2011, 59, 5173-5180. [CrossRef] [PubMed]

81. Agriopoulou, S.; Stamatelopoulou, E.; Varzakas, T. Advances in Analysis and Detection of Major Mycotoxins in Foods. Foods 2020, 9, 518. [CrossRef]

82. Zhang, B.; Chen, X.; Han, S.-Y.; Li, M.; Ma, T.-Z.; Sheng, W.-J.; Zhu, X. Simultaneous Analysis of 20 Mycotoxins in Grapes and Wines from Hexi Corridor Region (China): Based on a QuEChERS-UHPLC-MS/MS Method. Molecules 2018, 23, 1926. [CrossRef] 
83. Magan, N.; Olsen, M. Mycotoxins in Food: Detection and Control; Woodhead Publishing: Sawston, Cambridge, UK, 2004; ISBN 978-1-85573-733-4.

84. Rubert, J.; Dzuman, Z.; Vaclavikova, M.; Zachariasova, M.; Soler, C.; Hajslova, J. Analysis of Mycotoxins in Barley Using Ultra High Liquid Chromatography High Resolution Mass Spectrometry: Comparison of Efficiency and Efficacy of Different Extraction Procedures. Talanta 2012, 99, 712-719. [CrossRef]

85. Filigenzi, M.S.; Ehrke, N.; Aston, L.S.; Poppenga, R.H. Evaluation of a Rapid Screening Method for Chemical Contaminants of Concern in Four Food-Related Matrices Using QuEChERS Extraction, UHPLC and High Resolution Mass Spectrometry. Food Addit. Contam. Part. A 2011, 28, 1324-1339. [CrossRef]

86. Chiesa, L.M.; Nobile, M.; Malandra, R.; Pessina, D.; Panseri, S.; Labella, G.F.; Arioli, F. Food Safety Traits of Mussels and Clams: Distribution of PCBs, PBDEs, OCPs, PAHs and PFASs in Sample from Different Areas Using HRMS-Orbitrap ${ }^{\circledR}$ and Modified QuEChERS Extraction Followed by GC-MS/MS. Food Addit. Contam. Part A 2018, 35, 959-971. [CrossRef]

87. Mekonen, S.; Ambelu, A.; Spanoghe, P. Pesticide Residue Evaluation in Major Staple Food Items of Ethiopia Using the QuEChERS Method: A Case Study from the Jimma Zone. Environ. Toxicol. Chem. 2014, 33, 1294-1302. [CrossRef]

88. Andraščíková, M.; Hrouzková, S. A Comparative Study of Three Modifications of the QuEChERS Method for Determination of Endocrine Disrupting Pesticide Residues in Lemon Matrices by Fast GC-MS. Anal. Methods 2013, 5, 1374-1384. [CrossRef]

89. Musarurwa, H.; Chimuka, L.; Pakade, V.E.; Tavengwa, N.T. Recent Developments and Applications of QuEChERS Based Techniques on Food Samples during Pesticide Analysis. J. Food Compos. Anal. 2019, 84, 103314. [CrossRef]

90. Moretti, S.; Cruciani, G.; Romanelli, S.; Rossi, R.; Saluti, G.; Galarini, R. Multiclass Method for the Determination of 62 Antibiotics in Milk. J. Mass Spectrom. 2016, 51, 792-804. [CrossRef] [PubMed]

91. Mantzos, N.; Karakitsou, A.; Zioris, I.; Leneti, E.; Konstantinou, I. QuEChERS and Solid Phase Extraction Methods for the Determination of Energy Crop Pesticides in Soil, Plant and Runoff Water Matrices. Int. J. Environ. Anal. Chem. 2013, 93, 1566-1584. [CrossRef]

92. Zweigenbaum, J. (Ed.) Mass Spectrometry in Food Safety: Methods and Protocols; Methods in Molecular Biology; Humana Press: Totowa, NJ, USA, 2011; ISBN 978-1-61779-135-2.

93. Rejczak, T.; Tuzimski, T. A Review of Recent Developments and Trends in the QuEChERS Sample Preparation Approach. Open Chem. 2015, 1. [CrossRef]

94. Tamura, M.; Uyama, A.; Mochizuki, N. Development of a Multi-Mycotoxin Analysis in Beer-Based Drinks by a Modified QuEChERS Method and Ultra-High-Performance Liquid Chromatography Coupled with Tandem Mass Spectrometry. Anal. Sci. Int. J. Jpn. Soc. Anal. Chem. 2011, 27, 629-635. [CrossRef]

95. Bouafifssa, Y.; Manyes, L.; Rahouti, M.; Mañes, J.; Berrada, H.; Zinedine, A.; Fernández-Franzón, M. Multi-Occurrence of Twenty Mycotoxinsin Pasta and a Risk Assessment in the Moroccan Population. Toxins 2018, 10, 432. [CrossRef]

96. Streit, E.; Schatzmayr, G.; Tassis, P.; Tzika, E.; Marin, D.; Taranu, I.; Tabuc, C.; Nicolau, A.; Aprodu, I.; Puel, O.; et al. Current Situation of Mycotoxin Contamination and Co-Occurrence in Animal Feed-Focus on Europe. Toxins 2012, 4, 788-809. [CrossRef]

97. He, J.; Zhang, B.; Zhang, H.; Hao, L.-L.; Ma, T.-Z.; Wang, J.; Han, S.-Y. Monitoring of 49 Pesticides and 17 Mycotoxins in Wine by QuEChERS and UHPLC-MS/MS Analysis. J. Food Sci. 2019, 84, 2688-2697. [CrossRef]

98. Battilani, P.; Palumbo, R.; Giorni, P.; Dall'Asta, C.; Dellafiora, L.; Gkrillas, A.; Toscano, P.; Crisci, A.; Brera, C.; Santis, B.D.; et al. Mycotoxin Mixtures in Food and Feed: Holistic, Innovative, Flexible Risk Assessment Modelling Approach. EFSA Supporting Publ. 2020, 17, 1757E. [CrossRef]

99. Sun, J.; Li, W.; Zhang, Y.; Hu, X.; Wu, L.; Wang, B. QuEChERS Purification Combined with Ultrahigh-Performance Liquid Chromatography Tandem Mass Spectrometry for Simultaneous Quantification of 25 Mycotoxins in Cereals. Toxins $2016,8,375$. [CrossRef] [PubMed]

100. Frenich, A.G.; Romero-González, R.; Gómez-Pérez, M.L.; Vidal, J.L.M. Multi-Mycotoxin Analysis in Eggs Using a QuEChERSBased Extraction Procedure and Ultra-High-Pressure Liquid Chromatography Coupled to Triple Quadrupole Mass Spectrometry. J. Chromatogr. A 2011, 1218, 4349-4356. [CrossRef]

101. Alcántara-Durán, J.; Moreno-González, D.; García-Reyes, J.F.; Molina-Díaz, A. Use of a Modified QuEChERS Method for the Determination of Mycotoxin Residues in Edible Nuts by Nano Flow Liquid Chromatography High Resolution Mass Spectrometry. Food Chem. 2019, 279, 144-149. [CrossRef]

102. Cammilleri, G.; Pulvirenti, A.; Vella, A.; Macaluso, A.; Lo Dico, G.M.; Giaccone, V.; Giordano, V.; Vinciguerra, M.; Cicero, N.; Cicero, A.; et al. Tetracycline Residues in Bovine Muscle and Liver Samples from Sicily (Southern Italy) by LC-MS/MS Method: A Six-Year Study. Molecules 2019, 24, 695. [CrossRef]

103. Karageorgou, E.; Samanidou, V. Youden Test Application in Robustness Assays during Method Validation. J. Chromatogr. A 2014, 1353, 131-139. [CrossRef]

104. Beltrán, E.; Ibáñez, M.; Sancho, J.V.; Hernández, F. Determination of Mycotoxins in Different Food Commodities by Ultra-HighPressure Liquid Chromatography Coupled to Triple Quadrupole Mass Spectrometry. Rapid Commun. Mass Spectrom. 2009, 23, 1801-1809. [CrossRef] [PubMed]

105. Publications Office of the European Union. Report on the 2016 Proficiency Test of the European Union Reference Laboratory for Mycotoxins for the Network of National Reference Laboratories: Determination of Aflatoxin B1 in Defatted Peanut Powder. Available online: http:/ / op.europa.eu/it/publication-detail/- / publication/23623826-a267-11e7-a56f-01aa75ed71a1 (accessed on 17 August 2020). 
106. González-Curbelo, M.Á.; Socas-Rodríguez, B.; Herrera-Herrera, A.V.; González-Sálamo, J.; Hernández-Borges, J.; RodríguezDelgado, M.Á. Evolution and Applications of the QuEChERS Method. Trac. Trends Anal. Chem. 2015, 71, 169-185. [CrossRef]

107. Hidy, P.H.; Baldwin, R.S.; Greasham, R.L.; Keith, C.L.; Mcmullen, J.R. Zearalenone and Some Derivatives: Production and Biological Activities. In Advances in Applied Microbiology; Elsevier: Amsterdam, The Netherlands, 1977; Volume 22, pp. 59-82. ISBN 978-0-12-002622-7.

108. Moss, M.O. AFLATOXINS. In Encyclopedia of Food Sciences and Nutrition, 2nd ed.; Caballero, B., Ed.; Academic Press: Oxford, UK, 2003; pp. 66-72. ISBN 978-0-12-227055-0.

109. Visconti, A.; Doko, M.B.; Bottalico, C.; Schurer, B.; Boenke, A. Stability of Fumonisins (FB 1 and $\left.\mathrm{FB}_{2}\right)$ in Solution. Food Addit. Contam. 1994, 11, 427-431. [CrossRef]

110. Knutsen, H.-K.; Barregård, L.; Bignami, M.; Brüschweiler, B.; Ceccatelli, S.; Cottrill, B.; Dinovi, M.; Edler, L.; Grasl-Kraupp, B.; Hogstrand, C.; et al. Appropriateness to Set a Group Health Based Guidance Value for T2 and HT2 Toxin and Its Modified Forms. EFSA J. 2017, 15, e04655. [CrossRef]

111. Stahnke, H.; Kittlaus, S.; Kempe, G.; Alder, L. Reduction of Matrix Effects in Liquid Chromatography-Electrospray IonizationMass Spectrometry by Dilution of the Sample Extracts: How Much Dilution Is Needed? Anal. Chem. 2012, 84, 1474-1482. [CrossRef] [PubMed]

112. Liu, Y.; Han, S.; Lu, M.; Wang, P.; Han, J.; Wang, J. Modified QuEChERS Method Combined with Ultra-High Performance Liquid Chromatography Tandem Mass Spectrometry for the Simultaneous Determination of 26 Mycotoxins in Sesame Butter. J. Chromatogr. B 2014, 970, 68-76. [CrossRef]

113. Koesukwiwat, U.; Sanguankaew, K.; Leepipatpiboon, N. Evaluation of a Modified QuEChERS Method for Analysis of Mycotoxins in Rice. Food Chem. 2014, 153, 44-51. [CrossRef] [PubMed]

114. Vaclavik, L.; Zachariasova, M.; Hrbek, V.; Hajslova, J. Analysis of Multiple Mycotoxins in Cereals under Ambient Conditions Using Direct Analysis in Real Time (DART) Ionization Coupled to High Resolution Mass Spectrometry. Talanta 2010, 82, 1950-1957. [CrossRef] [PubMed]

115. Madureira, T.V.; Velhote, S.; Santos, C.; Cruzeiro, C.; Rocha, E.; Rocha, M.J. A Step Forward Using QuEChERS (Quick, Easy, Cheap, Effective, Rugged, and Safe) Based Extraction and Gas Chromatography-Tandem Mass Spectrometry-Levels of Priority Polycyclic Aromatic Hydrocarbons in Wild and Commercial Mussels. Environ. Sci. Pollut. Res. 2014, 21, 6089-6098. [CrossRef] [PubMed]

116. Giaccone, V.; Cammilleri, G.; Macaluso, A.; Cicero, N.; Pulvirenti, A.; Vella, A.; Ferrantelli, V. A LC-HRMS after QuEChERS Cleanup Method for the Rapid Determination of Dye Residues in Fish Products. Food Anal. Methods 2018, 11, 625-634. [CrossRef]

117. Rodríguez-Carrasco, Y.; Moltó, J.C.; Berrada, H.; Mañes, J. A Survey of Trichothecenes, Zearalenone and Patulin in Milled Grain-Based Products Using GC-MS/MS. Food Chem. 2014, 146, 212-219. [CrossRef]

118. Galluzzo, F.G.; Cammilleri, G.; Pantano, L.; Cascio, G.L.; Pulvirenti, A.; Macaluso, A.; Vella, A.; Ferrantelli, V. Acrylamide Assessment of Wheat Bread Incorporating Chia Seeds (Salvia Hispanica L.) by LC-LM/MS. Food Addit. Contam. Part. A 2021, 38, 1-8. [CrossRef]

119. Smeraglia, J.; Baldrey, S.F.; Watson, D. Matrix Effects and Selectivity Issues in LC-MS-MS. Chromatographia 2002, 55, S95-S99. [CrossRef]

120. Cortese, M.; Gigliobianco, M.R.; Magnoni, F.; Censi, R.; Di Martino, P. Compensate for or Minimize Matrix Effects? Strategies for Overcoming Matrix Effects in Liquid Chromatography-Mass Spectrometry Technique: A Tutorial Review. Molecules 2020, 25, 3047. [CrossRef] [PubMed]

121. De Nicolò, A.; Cantù, M.; D’Avolio, A. Matrix Effect Management in Liquid Chromatography Mass Spectrometry: The Internal Standard Normalized Matrix Effect. Bioanalysis 2017, 9, 1093-1105. [CrossRef] [PubMed]

122. Fabregat-Cabello, N.; Zomer, P.; Sancho, J.V.; Roig-Navarro, A.F.; Mol, H.G.J. Comparison of Approaches to Deal with Matrix Effects in LC-MS/MS Based Determinations of Mycotoxins in Food and Feed. World Mycotoxin J. 2016, 9, 149-161. [CrossRef]

123. Boevre, M.D.; Mavungu, J.D.D.; Maene, P.; Audenaert, K.; Deforce, D.; Haesaert, G.; Eeckhout, M.; Callebaut, A.; Berthiller, F.; Peteghem, C.V.; et al. Development and Validation of an LC-MS/MS Method for the Simultaneous Determination of Deoxynivalenol, Zearalenone, T-2-Toxin and Some Masked Metabolites in Different Cereals and Cereal-Derived Food. Food Addit. Contam. Part. A 2012, 29, 819-835. [CrossRef] [PubMed]

124. Zhang, L.; Dou, X.-W.; Zhang, C.; Logrieco, A.F.; Yang, M.-H. A Review of Current Methods for Analysis of Mycotoxins in Herbal Medicines. Toxins 2018, 10, 65. [CrossRef] [PubMed]

125. Yogendrarajah, P.; Van Poucke, C.; De Meulenaer, B.; De Saeger, S. Development and Validation of a QuEChERS Based Liquid Chromatography Tandem Mass Spectrometry Method for the Determination of Multiple Mycotoxins in Spices. J. Chromatogr. A 2013, 1297, 1-11. [CrossRef] [PubMed]

126. Lattanzio, V.M.T.; Solfrizzo, M.; Powers, S.; Visconti, A. Simultaneous Determination of Aflatoxins, Ochratoxin A and Fusarium Toxins in Maize by Liquid Chromatography/Tandem Mass Spectrometry after Multitoxin Immunoaffinity Cleanup. Rapid Commun. Mass Spectrom. 2007, 21, 3253-3261. [CrossRef] [PubMed]

127. Spanjer, M.C.; Rensen, P.M.; Scholten, J.M. LC-MS/MS Multi-Method for Mycotoxins after Single Extraction, with Validation Data for Peanut, Pistachio, Wheat, Maize, Cornflakes, Raisins and Figs. Food Addit. Contam. Part. A 2008, 25, 472-489. [CrossRef] [PubMed] 
128. EUR-Lex-02006R0401-20140701-EN-EUR-Lex. Available online: https:// eur-lex.europa.eu/legal-content/EN/TXT/?uri= CELEX\%3A02006R0401-20140701 (accessed on 6 November 2020).

129. Kmellár, B.; Abrankó, L.; Fodor, P.; Lehotay, S.J. Routine Approach to Qualitatively Screening 300 Pesticides and Quantification of Those Frequently Detected in Fruit and Vegetables Using Liquid Chromatography Tandem Mass Spectrometry (LC-MS/MS). Food Addit. Contam. Part. A 2010, 27, 1415-1430. [CrossRef]

130. Stachniuk, A.; Szmagara, A.; Czeczko, R.; Fornal, E. LC-MS/MS Determination of Pesticide Residues in Fruits and Vegetables. J. Environ. Sci. HealthPart. B 2017, 52, 446-457. [CrossRef] [PubMed]

131. He, Z.; Wang, Y.; Xu, Y.; Liu, X. Determination of Antibiotics in Vegetables Using QuEChERS-Based Method and Liquid Chromatography-Quadrupole Linear Ion Trap Mass Spectrometry. Food Anal. Methods 2018, 11, 2857-2864. [CrossRef]

132. Camilleri, J.; Vulliet, E. Determination of Steroid Hormones in Sediments Based on Quick, Easy, Cheap, Effective, Rugged, and Safe (Modified-QuEChERS) Extraction Followed by Liquid Chromatography-Tandem Mass Spectrometry (LC-MS/MS). Anal. Methods 2015, 7, 9577-9586. [CrossRef]

133. Sulyok, M.; Krska, R.; Schuhmacher, R. Application of an LC-MS/MS Based Multi-Mycotoxin Method for the Semi-Quantitative Determination of Mycotoxins Occurring in Different Types of Food Infected by Moulds. Food Chem. 2010, 119, 408-416. [CrossRef]

134. Folloni, S.; Bellocchi, G.; Kagkli, D.-M.; Pastor-Benito, S.; Aguilera, M.; Mazzeo, A.; Querci, M.; Van den Eede, G.; Ermolli, M. Development of an ELISA Reverse-Based Assay to Assess the Presence of Mycotoxins in Cereal Flour. Food Anal. Methods 2011, 4, 221-227. [CrossRef]

135. Oplatowska-Stachowiak, M.; Reiring, C.; Sajic, N.; Haasnoot, W.; Brabet, C.; Campbell, K.; Elliott, C.T.; Salden, M. Development and In-House Validation of a Rapid and Simple to Use ELISA for the Detection and Measurement of the Mycotoxin Sterigmatocystin. Anal. Bioanal. Chem. 2018, 410, 3017-3023. [CrossRef] [PubMed]

136. Sun, D.; Qiu, N.; Zhou, S.; Lyu, B.; Zhang, S.; Li, J.; Zhao, Y.; Wu, Y. Development of Sensitive and Reliable UPLC-MS/MS Methods for Food Analysis of Emerging Mycotoxins in China Total Diet Study. Toxins 2019, 11, 166. [CrossRef] [PubMed]

137. Ren, Y.; Zhang, Y.; Shao, S.; Cai, Z.; Feng, L.; Pan, H.; Wang, Z. Simultaneous Determination of Multi-Component Mycotoxin Contaminants in Foods and Feeds by Ultra-Performance Liquid Chromatography Tandem Mass Spectrometry. J. Chromatogr. A 2007, 1143, 48-64. [CrossRef]

138. Azaiez, I.; Giusti, F.; Sagratini, G.; Mañes, J.; Fernández-Franzón, M. Multi-Mycotoxins Analysis in Dried Fruit by LC/MS/MS and a Modified QuEChERS Procedure. Food Anal. Methods 2014, 7, 935-945. [CrossRef]

139. Njumbe Ediage, E.; Van Poucke, C.; De Saeger, S. A Multi-Analyte LC-MS/MS Method for the Analysis of 23 Mycotoxins in Different Sorghum Varieties: The Forgotten Sample Matrix. Food Chem. 2015, 177, 397-404. [CrossRef]

140. Oliveira, M.S.; Rocha, A.; Sulyok, M.; Krska, R.; Mallmann, C.A. Natural Mycotoxin Contamination of Maize (Zea Mays L.) in the South Region of Brazil. Food Control. 2017, 73, 127-132. [CrossRef]

141. Abdallah, M.F.; Girgin, G.; Baydar, T.; Krska, R.; Sulyok, M. Occurrence of Multiple Mycotoxins and Other Fungal Metabolites in Animal Feed and Maize Samples from Egypt Using LC-MS/MS. J. Sci. Food Agric. 2017, 97, 4419-4428. [CrossRef]

142. Tansakul, N.; Jala, P.; Laopiem, S.; Tangmunkhong, P.; Limsuwan, S. Co-Occurrence of Five Fusarium Toxins in Corn-Dried Distiller's Grains with Solubles in Thailand and Comparison of ELISA and LC-MS/MS for Fumonisin Analysis. Mycotoxin Res. 2013, 29, 255-260. [CrossRef] [PubMed]

143. Milani, J.; Maleki, G. Effects of Processing on Mycotoxin Stability in Cereals. J. Sci. Food Agric. 2014, 94, 2372-2375. [CrossRef] [PubMed]

144. Magan, N.; Aldred, D.; Mylona, K.; Lambert, R.J.W. Limiting Mycotoxins in Stored Wheat. Food Addit. Contam. Part. A Chem. Anal. Control. Expo. Risk Assess. 2010, 27, 644-650. [CrossRef] [PubMed]

145. Santos, L.; Marín, S.; Sanchis, V.; Ramos, A.J. Screening of Mycotoxin Multicontamination in Medicinal and Aromatic Herbs Sampled in Spain. J. Sci. Food Agric. 2009, 89, 1802-1807. [CrossRef]

146. Gratz, S.W. Do Plant-Bound Masked Mycotoxins Contribute to Toxicity? Toxins 2017, 9, 85. [CrossRef] 